\title{
THE EFFECT OF HIGH SPERM CONCENTRATIONS ON THE RATES OF RESPIRATION AND FRUCTOLYSIS BY RAM SPERMATOZOA*
}

\author{
D. AMIR AND H. SGHINDLER \\ The National and University Institute of Agriculture, \\ Rehovoth, Israel \\ (Received 17th Fanuary 1966)
}

\begin{abstract}
Summary. The rates of oxygen consumption and fructolysis were measured in suspensions of washed spermatozoa at concentrations ranging from $1 \times 10^{9}$ to $7 \times 10^{9} / \mathrm{ml}$. Within that range the respiratory rate was independent of sperm concentration, provided that the oxygen diffusion was adequate. Similarly, the rate of fructolysis under anaerobic conditions and constant $\mathrm{pH}$ was not influenced by high sperm densities.
\end{abstract}

\section{INTRODUCTION}

It has been stated that an increase of the sperm concentration in suspensions containing more than $10^{9}$ cells $/ \mathrm{ml}$ results in a decrease of the oxygen consumption rate (Winchester \& McKenzie, 1941a; Henle \& Zittle, 1942; Bishop \& Salisbury, 1955). Various explanations have been offered to account for this phenomenon. Henle \& Zittle (1942), Lardy, Winchester \& Phillips (1945) and Rothschild \& Tuft (1950) attributed the decreasing rate to insufficient oxygen diffusion. Henle \& Zittle (1942) proposed an additional explanation, namely, that the effect of 'crowding' at high sperm concentrations may depress spermatozoal activity and hence lower the rate of oxygen uptake. Bishop \& Salisbury (1955) found that even when they increased the ratio of surface area to volume of the sperm suspension in order to ensure adequate aeration, there still existed an inverse relationship between cell concentration and oxygen uptake per cell; they suggested the presence of a metabolite or of a specific metabolic inhibitor associated with the sperm cells, which affects the rate of respiration.

The question whether high sperm concentration in itself affects the rate of sperm metabolism is of particular interest in view of the high sperm concentration $\left(5 \times 10^{9}\right.$ to $\left.10 \times 10^{9} \mathrm{cells} / \mathrm{ml}\right)$ prevailing in the epididymal semen of rams and bulls (White, Larsen \& Wales, 1959; Bennett \& Rowson, 1963; and unpublished observations in our laboratory). It may also be questioned whether in the presence of such highly concentrated sperm suspensions the technique used by Bishop \& Salisbury (1955) is adequate to rule out limitations in the rate of

\footnotetext{
* Contribution from the National and University Institute of Agriculture, Rehovoth, Israel; 1965 series, No. 962-E.
} 
oxygen uptake resulting from insufficient aeration. It was, therefore, decided to re-examine the rate of oxygen uptake at high sperm concentrations, paying specific attention to the role of oxygen diffusion, and to combine that study with an investigation of the effect of high sperm concentrations on the rate of anaerobic fructolysis in such highly dense suspensions.

\section{Semen}

\section{MATERIALS AND METHODS}

Pooled ejaculates from rams were used. Sperm motility was assessed in semen by the presence of wave motion, or in diluted samples as percentage of motile cells (PMC). The sperm density was measured with an EEL photoelectric colorimeter calibrated against haemocytometer counts. Only ejaculates with good wave motion and a density of at least $4 \times 10^{9} \mathrm{cells} / \mathrm{ml}$ were used. The diluents were buffers made up of $0.14 \mathrm{M}-\mathrm{Na}_{2} \mathrm{HPO}_{4} \cdot 12 \mathrm{H}_{2} \mathrm{O}$ and $0.19 \mathrm{M}$ $\mathrm{NaH}_{2} \mathrm{PO}_{4} \cdot 2 \mathrm{H}_{2} \mathrm{O}$ so as to provide $\mathrm{pH}$ from $7 \cdot 0$ to $7 \cdot 8$.

\section{Sperm suspensions}

The semen was centrifuged at $1500 \mathrm{~g}$ for $15 \mathrm{~min}$; the seminal plasma was removed and replaced by an equal volume of buffer, $\mathrm{pH} 7 \cdot 2$. After resuspending the spermatozoa by gently stirring with a glass rod, a second centrifugation was carried out as above. The centrifuged spermatozoa were resuspended in buffers at $\mathrm{pH} 7.6$ to $7 \cdot 8$ so as to give a concentration of $7 \times 10^{9}$ to $8 \times 10^{9}$ spermatozoa $/ \mathrm{ml}$. From this suspension samples were taken for measurement of oxygen uptake and fructolysis. The remaining suspension was further diluted with buffer at $\mathrm{pH} 7 \cdot 2$ to give a concentration of about $4 \times 10^{9} \mathrm{spermatozoa} / \mathrm{ml}$. The procedure of taking samples, and diluting the remainder, was repeated to give suspensions of about $2 \times 10^{9}$ and $1 \times 10^{9}$ spermatozoa/ml, using buffers at $\mathrm{pH} 7 \cdot 1$ and $7 \cdot 0$, respectively. The final $\mathrm{pH}$ of all the samples was $7 \cdot 0$ to $7 \cdot 2$. This range was found (Winchester \& McKenzie, 1941b) to be optimal for the metabolic activity of ram spermatozoa. The fructose concentration in the washed and diluted suspensions was negligible, and the motility of spermatozoa appeared to have been unaffected.

\section{Oxygen uptake}

This was measured manometrically by the direct method of Warburg (Umbreit, Burris \& Stauffer, 1957) at $37^{\circ} \mathrm{C}$ in duplicates. The shaking rate was 110 strokes $/ \mathrm{min}$. The gas phase was either air or oxygen. For the latter, the manometer-flask assemblies were simultaneously saturated with oxygen at room temperature and then transferred to the Warburg water bath. Preliminary experiments showed that the semen lost some of its vitality when the various operations necessary for flushing the system with oxygen were carried out inside the warm water bath of the Warburg apparatus. Readings were made every 15 $\min$ for $1 \mathrm{hr}$.

\section{Fructolysis}

Fructose was added to the washed semen samples to give a concentration of about $11 \mathrm{mg} / \mathrm{ml}$ and the samples incubated for $20 \mathrm{~min}$ at $37^{\circ} \mathrm{C}$ under anaerobic 
conditions; the $\mathrm{pH}$ was maintained constantly at 7.0 by automatic titration (Nevo, Caplan \& Schindler, 1963), using $0.18 \mathrm{~N}-\mathrm{NaOH}$ for the samples with a density of up to $2 \times 10^{9}$ cells $/ \mathrm{ml}$, and $0.28 \mathrm{~N}-\mathrm{NaOH}$ for the samples with higher densities. By maintaining constant $\mathrm{pH}$ it is possible to avoid the effect of the decreasing $\mathrm{pH}$ on the rate of fructolysis (Salisbury \& Kinney, 1957; Norman, Johnson, Porterfield \& Dunbar, 1958; De Groot, 1963) which occurs particularly when samples of highest sperm density are used, even in the presence of buffer. The short incubation period was used in order to prevent the accumulation of large amounts of lactate which, according to our unpublished data, have a depressing effect on the rate of fructolysis.

Fructose concentrations before and after incubation were assessed, as described by Mann (1948), in duplicate samples. A cold solution of $10 \%$ trichloroacetic acid was used for deproteinization (Erb, Flerchinger, Ehlers \& Gassner, 1956). This deproteinization method was found to be reliable because the recovery of the added amounts of fructose was complete and independent of the sperm density of the samples. Lactate concentration before and after incubation was determined with the enzymatic method (Barker \& Britton, 1957) using Boehringer reagents (Biochemica Test Combination TC-B 15972, C. F. Boehringer \& Soehne GmbH, Mannheim, Germany).

Since the sampling for fructose and lactic acid determinations could not be made simultaneously in the different sperm suspensions, and since the use of the automatic titration method permitted the measurement of only one sample at a time, it became necessary to test the different samples in sequence. In order to avoid the possible influence of the lapse of time resulting from that procedure, a latin square design (experimental densities $\times$ order of examination) was used.

\section{Statistical analysis}

The results were subjected to an analysis of variance and the significance of the differences between the means of the various treatments was ascertained using the $q$ test (Federer, 1955).

\section{Oxygen uptake}

\section{RESULTS}

Three experiments were carried out. In Expt. 1, which included four replicates, the oxygen consumption was measured in $1 \mathrm{ml}$ samples of four suspensions with different sperm density, using Warburg flasks of 9-ml volume filled with air. In Expts. 2 and 3 the following steps were taken in order to increase the oxygen diffusion. In Expt. 2, which included five replicates, the ratio of surface area to sample volume was increased by using $0 \cdot 5-\mathrm{ml}$ samples in flasks of $22 \mathrm{ml}$ volume, which had been filled with air. In Expt. 3 the samples were incubated in an oxygen atmosphere while control samples were incubated in air; the volume of the samples and flasks was the same as in Expt. 2. Owing to the limited space available for the Warburg manometers, not all samples could be investigated simultaneously; therefore only two sperm concentrations were compared at a time: $1 \times 10^{9}$ with $2 \times 10^{9}$ cells $/ \mathrm{ml} ; 2 \times 10^{9}$ with $4 \times 10^{9} \mathrm{cells} / \mathrm{ml}$; and $4 \times 10^{9}$ with $7 \times 10^{9}$ cells $/ \mathrm{ml}$; six replicates were used for each pair. The results of all three experiments are presented in Table 1. 
TABLE 1

RATES OF OXYGEN UPTAKE $\left(\mu \mathrm{l} \mathrm{O}_{2} / 10^{9}\right.$ SPERM/ml) AT DIFFERENT SPERM DENSITIES IN THE PRESENCE OF AIR OR OXYGEN

\begin{tabular}{|c|c|c|c|c|c|c|c|c|}
\hline & Air & Oxygen & Air & Oxygen & Air & Oxygen & Air & Oxygen \\
\hline \multicolumn{9}{|l|}{ Experiment 1} \\
\hline Sperm concentration $\left(\times 10^{9} / \mathrm{ml}\right)$ & $1 \cdot 0$ & & $2 \cdot 2$ & & $3 \cdot 8$ & & $7 \cdot 7$ & \\
\hline $\begin{array}{l}\text { Rate of oxygen uptake } \\
\text { Motility after incubation (PMC) }\end{array}$ & $\begin{array}{l}79 \cdot 1^{a} \\
15\end{array}$ & & $\begin{array}{l}41 \cdot 8^{b} \\
25\end{array}$ & & $\begin{array}{l}29 \cdot 0^{\mathrm{e}} \\
25\end{array}$ & & $\begin{array}{l}17 \cdot 5^{\mathrm{d}} \\
25\end{array}$ & \\
\hline \multicolumn{9}{|l|}{ Experiment 2} \\
\hline Sperm concentration $\left(\times 10^{9} / \mathrm{ml}\right)$ & 1.0 & & $2 \cdot 1$ & & $3 \cdot 9$ & & $7 \cdot 3$ & \\
\hline $\begin{array}{l}\text { Rate of oxygen uptake } \\
\text { Motility after incubation (PMC) }\end{array}$ & $\begin{array}{l}92 \cdot 9^{a} \\
22\end{array}$ & & $\begin{array}{l}114 \cdot 4^{b} \\
26\end{array}$ & & $\begin{array}{l}115 \cdot 0^{\circ} \\
50\end{array}$ & & $\begin{array}{l}75 \cdot 8^{\mathrm{e}} \\
57\end{array}$ & \\
\hline \multicolumn{9}{|l|}{ Experiment 3} \\
\hline Sperm concentration $\left(\times 10^{9} / \mathrm{ml}\right)$ & $1 \cdot 1$ & $1 \cdot 1$ & $2 \cdot 1$ & $2 \cdot \mathrm{I}$ & $3 \cdot 8$ & $3 \cdot 8$ & $7 \cdot 4$ & $7 \cdot 4$ \\
\hline $\begin{array}{l}\text { Rate of oxygen uptake } \\
\text { Motility after incubation (PMC) }\end{array}$ & $\begin{array}{l}114 \cdot 6^{\mathrm{a}} \\
22\end{array}$ & $\begin{array}{l}115 \cdot 3^{a} \\
22\end{array}$ & $\begin{array}{l}111 \cdot 6^{b} \\
22\end{array}$ & $\begin{array}{l}108 \cdot 9^{a} \\
23\end{array}$ & & & & \\
\hline $\begin{array}{l}\text { Rate of oxygen uptake } \\
\text { Motility after incubation (PMC) }\end{array}$ & & & $\begin{array}{l}126 \cdot 2^{a} \\
38\end{array}$ & $118 \cdot 1^{b}$ & $\begin{array}{l}124 \cdot 5^{a} \\
30\end{array}$ & $\begin{array}{l}133 \cdot 5^{\mathrm{c}} \\
33\end{array}$ & & \\
\hline $\begin{array}{l}\text { Rate of oxygen uptake } \\
\text { Motility after incubation (PMC) }\end{array}$ & & & & & $\begin{array}{l}102 \cdot 0^{a} \\
43\end{array}$ & $\begin{array}{l}124 \cdot 5^{b} \\
38\end{array}$ & $\begin{array}{l}74 \cdot 2^{\mathrm{c}} \\
40\end{array}$ & $\begin{array}{l}115 \cdot 2^{d} \\
39\end{array}$ \\
\hline
\end{tabular}

Oxygen uptake was measured during $1 \mathrm{hr}$ at $37^{\circ} \mathrm{C}$ after a 15 -min equilibration period. The $\mathrm{pH}$ of the samples at the end of the incubation period was $7 \cdot 1$ to 7.2 in all samples, with the exception of the $7.4 \times 10^{9}$ spermatozoa $/ \mathrm{ml}$ sample in oxygen (Expt. 3) where $\mathrm{pH}$ was 7.4 .

Experiment 1:1.0 ml of sperm suspension in a 9-ml flask, four replicates.

Experiments 2 and $3: 0.5 \mathrm{ml}$ of sperm suspension in a 22-ml flask, five and six replicates, respectively. PMC denotes the percentage of motile cells estimated after further dilution of the samples.

Any two mean values not marked with a common superscript (a, b, $c$ or d) differ significantly $(P<0.05)$. Comparisons to be made in horizontal rows.

TABLE 2

RATE OF FRUCTOSE DISAPPEARANCE AND LACTIC ACID ACCUMULATION $\left(\mu \mathrm{g} / 10^{9}\right.$ SPERM/20 $\left.\mathrm{min}\right)$ AT DIFFERENT SPERM DENSITIES UNDER ANAEROBIC CONDITIONS AND CONSTANT pH 7.0 (MEAN OF SIXTEEN REPLICATES)

\begin{tabular}{l|c|c|c|c}
\hline & \multicolumn{4}{|c}{ Sperm concentration $\left(\times 10^{9} / \mathrm{ml}\right)$} \\
\cline { 2 - 5 } & $1 \cdot 3$ & $2 \cdot 3$ & $3 \cdot 9$ & $7 \cdot 1$ \\
\hline Rate of fructose disappearance & $576^{\mathrm{a}}$ & $675^{\mathrm{ab}}$ & $714^{\mathrm{b}}$ & $672^{\mathrm{a}}$ \\
Rate of lactic acid accumulation & $448^{\mathrm{a}}$ & $511^{\mathrm{b}}$ & $506^{\mathrm{b}}$ & $369^{\mathrm{c}}$ \\
Motility after incubation (PMC) & 34 & $37^{\mathrm{b}}$ & 33 & 26 \\
\hline
\end{tabular}

Any two mean values not marked with a common superscript (a, b or c) differ significantly $(P<0 \cdot 05)$. Comparisons to be made in horizontal rows.

PMC denotes the percentage of motile cells estimated after further dilution of the samples. 
By comparing results of Expts. 1 and 2 it can be seen that the ratio of surface area to sample volume significantly influenced the oxygen uptake by spermatozoa. Whereas in Expt. 1 the oxygen uptake decreased significantly with the increase of the sperm density, in Expt. 2 it was highest at the density levels of $2 \times 10^{9}$ and $4 \times 10^{9}$ cells $/ \mathrm{ml}$, and an adverse effect was noticed only at the highest level.

Experiment 3 showed no difference in oxygen uptake between the samples incubated in oxygen and air so long as sperm density was $1 \times 10^{9}$ or $2 \times 10^{9}$ cells $/ \mathrm{ml}$. However, the presence of oxygen significantly enhanced the oxygen uptake at higher density levels $\left(4 \times 10^{9}\right.$ and $7 \times 10^{9}$ spermatozoa $\left./ \mathrm{ml}\right)$. The effect was very pronounced at the density level of $7 \times 10^{9}$ cells $/ \mathrm{ml}$.

\section{Fructolysis}

The rate of fructose disappearance $\left(\mu \mathrm{g} / 10^{9}\right.$ spermatozoa) was lowest in the samples containing $1.3 \times 10^{9}$ spermatozoa and that of lactic acid accumulation was lowest in the samples with $7 \cdot 1 \times 10^{9}$ spermatozoa/ml (Table 2). In all, however, no significant interaction of sperm density $\times$ order of examination of the different samples was found.

\section{DISGUSSION}

It appears from our results that the rate of oxygen uptake is not affected by sperm densities up to $7 \times 10^{9} \mathrm{cells} / \mathrm{ml}$, provided that the oxygen diffusion is adequate. This finding confirms the assumption made by previous investigators (Henle \& Zittle, 1942; Lardy et al., 1945) that the decrease in the rate of oxygen uptake by the spermatozoa at high sperm densities was due to insufficient oxygen diffusion through the samples. Rothschild (1948) and Rothschild \& Tuft (1950), working with sea-urchin spermatozoa, found that 'the oxygen uptake of dense sperm suspensions $\left(>10^{9} \mathrm{sperm} / \mathrm{ml}\right.$ ) is altered by changes in oxygen tension' and that 'in very dense suspension $\left(>5 \times 10^{9}\right.$ cells $\left./ \mathrm{ml}\right)$ the apparent low oxygen uptake per unit quantity of spermatozoa is mainly due to inadequate oxygen saturation of the lower layers of the suspension'. All in all, our results suggest that it is not necessary to assume the presence of a specific factor associated with the sperm cells to explain the reported inverse relationship between the rate of oxygen uptake and the sperm density.

In the present work the results of fructose disappearance and lactic acid accumulation showed no trend which could be associated with the sperm concentration. It appears, therefore, that the fructolytic rate is not affected by the high sperm concentration, provided that a decrease in $\mathrm{pH}$ and the accumulation of large amounts of lactate during the incubation are prevented.

Do the above results have implications as regards the metabolic behaviour of spermatozoa inside the epididymis? Although in the present study ejaculated spermatozoa have been used, the conclusions drawn here should be applicable to epididymal spermatozoa in vitro, since there are indications (White \& Wales, 1961 ; Wallace \& Wales, 1964; Lindahl \& Thunqvist, 1964) that the metabolic pattern of epididymal spermatozoa in vitro does not differ essentially from that of ejaculated spermatozoa. The present study has shown that the rate of oxygen 
consumption by the spermatozoa in highly concentrated suspensions may be limited by insufficient oxygen diffusion, due to excessive thickness of the sample layer, or too low oxygen tension in the medium. Oxygen measurements inside the epididymal duct have not been carried out, but it has been shown by Cross \& Silver (1962) that the oxygen tension in the immediate surroundings of the epididymal duct is 16 to $34 \mathrm{~mm} \mathrm{Hg}$. At this level of oxygen tension, and assuming an average rate of oxygen uptake of $16 \mu \mathrm{l} \mathrm{O} / \mathrm{min} / 8 \times 10^{9}$ cells, one arrives, using Warburg's formula and Krogh's diffusion constant for oxygen,* at a figure of 120 to $170 \mu$ for the distance from the surface of the sperm suspension at which an oxygen concentration of zero has just been attained. However, the duct in the cauda epididymidis, in the bull at least, is said to have a diameter of about $1 \mathrm{~mm}$ (Blom, 1962). Therefore, presumably, the oxygen consumption by spermatozoa inside the epididymis, can take place only in that area of the epididymal duct which is located directly beneath the epithelial lining, leaving a cylindrical space in the centre of the duct under anaerobic conditions.

$* d^{\prime}=\sqrt{ }\left[8 C_{0}(D / A)\right]$ where $d^{\prime}$ is the limiting thickness, i.e. the thickness in $\mathrm{cm}$ of a tissue slice for an oxygen concentration of zero just to be attained at its midplane; $D$, the diffusion constant for $\mathrm{O}_{2}$, i.e.

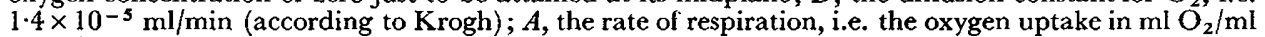
tissue/min; and $C_{0}$, the $\mathrm{O}_{2}$ concentration outside the slice (atm.) (Umbreit et al., 1957).

\section{AGKNOWLEDGMENTS}

This research has been financed in part by a grant made by the United States Department of Agriculture, under P.L.480.

The authors are grateful to $\operatorname{Dr} A$. Nevo for valuable suggestions in the preparation of the manuscript, and to Miss O. Kempenich for assistance.

\section{REFERENCES}

Barker, J. N. \& Britton, H. G. (1957) The enzymatic estimation of L(+) lactic acid. F. Physiol., Lond. 138, 3P.

Bennett, J. P. \& Rowson, L. E. A. (1963) A fistula for the collection of epididymal semen from the bull. 7. Reprod. Fert. 6, 61 .

Bishop, M. W. H. \& SAlisbury, G. W. (1955) Effect of sperm concentration on the oxygen uptake of bull semen. Am. F. Physiol. 180, 107.

Вцом, E. (1962) Male reproductive organs of farm animals. Reproduction in Farm Animals. Ed. E. S. E. Hafez. Lea \& Febiger, Philadelphia.

Cross, B. A. \& Silver, I. A. (1962) Neurovascular control of oxygen tension in the testis and epididymis. 7. Reprod. Fert. 3, 377.

DE Groot, B. (1963) The influence of $\mathrm{pH}$ on fructolysis and methylene blue reduction rate of bull spermatozoa. Tijdschr. Diergeneesk. 88, 489.

ERb, R. E., Flerchinger, F. H., Ehlers, M. H. \& Gassner, F. X. (1956) Metabolism of bull semen. II. Fructolysis relationships with sperm concentration and fertility. F. Dairy Sci. 39, 326.

Federer, W. T. (1955) Experimental design. MacMillan, New York.

Henle, Gertrude \& Zittre, C. A. (1942) Studies on metabolism of epididymal spermatozoa. Am. 7 . Physiol. 136, 70.

Lardy, H. A., Winchester, B. \& Phillips, P. H. (1945) The respiratory metabolism of ram spermatozoa. Archs Biochem. 6, 33.

Lindahl, P. E. \& ThUnQvist, L. O. (1964) Effects of low oxygen pressures on the oxygen consumption of bull spermatozoa. Ark. Zool. 2nd Series, 16, 367.

Mann, T. (1948) Fructose content and fructolysis in semen. Practical application in the evaluation of semen quality. F. agric. Sci. 38, 323. 
Nevo, A., CAplan, S. R. \& Schindler, H. (1963) Duration of motility and glycolysis of fowl spermatozoa in vitro under anaerobic conditions, constant $\mathrm{pH}$ and constant glucose concentration. $\mathcal{J}$. Reprod. Fert. 6, 361.

Norman, C., Johnson, G. E., Porterfield, I. D. \& Dunbar, R. S., Jr. (1958) Effect of pH on the life-span and metabolism of bovine sperm kept at room temperatures. F. Dairy Sci. 41, 1803.

Rothschild, LoRD (1948) The physiology of sea-urchin spermatozoa. Senescence and the dilution effect. 7. exp. Biol. 24, 353.

Rothschild, LoRd \& TUFr, P. H. (1950) The physiology of sea-urchin spermatozoa. F. exp. Biol. 27, 59.

Salisbury, G. W. \& KinNEy, W. C., JR. (1957) Factors influencing metabolic activity of bull spermatozoa. III. pH. F. Dairy Sci. 40. 1343.

Umbreit, W. W., BurRis, R. H. \& Stauffer, J. F. (1957) Manometric techniques. Burgess, Minneapolis.

WALLACE, J. C. \& WALEs, R. G. (1964) Effect of ions on the metabolism of ejaculated and epididymal ram spermatozoa. F. Reprod. Fert. 8, 187.

White, I. G., Larsen, L. H. \& Wales, R. G. (1959) Method for the in vivo collection of epididymal spermatozoa and for their comparison with ejaculated cells. Fert. Steril. 10, 571.

White, I. G. \& Wales, R. G. (1961) Comparison of epididymal and ejaculated semen of the ram. 7. Reprod. Fert. 2, 225.

Winchester, C. F. \& MCKenzie, F. F. (1941a) Influence of cell concentration on respiration rate of sperm. Proc. Soc. exp. Biol. Med. 48, 648.

Winchester, C. F. \& MCKenzie, F. F. (1941b) Influence of H-ion concentration on respiration of ram spermatozoa. Proc. Soc. exp. Biol. Med. 48, 654. 